\title{
Effects of lactation number and different stage of lactation on milk yield of Indigenous and Crossbred cows in Bangladesh
}

\author{
Ahmad $\mathrm{S}^{1}$, Hossain $\mathrm{FMA}^{2^{*}}$ and Islam $\mathrm{N}^{1}$ \\ ${ }^{I}$ Department of Dairy Science, Bangladesh Agricultural University, Bangladesh, ${ }^{2}$ Department of Dairy \& \\ Poultry Science, Sylhet Agricultural University, Bangladesh
}

[Received: 23 December 2011, Accepted: 20 March 2011]

\begin{abstract}
A total of 54 samples were collected from 18 milking cows from which nine were indigenous and nine were crossbred to evaluate the effects of different lactation number and different stage of lactation on the milk yield. The average daily milk yield of indigenous and crossbred cows at $1 \mathrm{st}, 2 \mathrm{nd}$ and 3rd lactation were 1.311, 1.633, 2.072 and 8.917, 9.567, 10.167 liter/day/cow respectively and represented the significant difference $(\mathrm{p}<0.01)$ within the daily milk yield of different lactations. Milk yield increased gradually from 1 st to 3rd lactation. The highest milk yield was recorded in 3rd lactation and lowest was in 1st. The mean milk yield of indigenous and crossbred cows at early, middle \& later stages of lactations were 1.617, 2.094, 1.306 and 9.389, 10.222, 9.039 liter/cow/day respectively that revealed stages of lactation had significant effect $(\mathrm{p}<0.01)$ on milk yield per day. It was observed that milk yield decreased after 2 nd stage of lactation and decreased linearly up to the end of lactation. The highest milk yield was recorded in 2nd stage of lactation and lowest was in 3rd stage of lactation. The overall milk production in different lactation for indigenous cows was 1.672 liter/day and for crossbred cows was 9.550 liter/day that may be concluded as crossbred cows are superior to indigenous in concern of milk yield.
\end{abstract}

Keywords: Indigenous cows, crossbred cows, lactation number, stage of lactation, milk yield.

\section{INTRODUCTION}

Undoubtedly it was established that the milk and milk products form an important well balanced food and almost complete food for human diet and there is no single food that can substitute the milk ${ }^{[1]}$. Though the milk being an important food for mankind, the people of our country is depriving for unavailability of milk for long time. The annual milk production in Bangladesh is nearly 1.62 million metric ton which is very low in respect of our demand. The availability of milk in our country is only $33.95 \mathrm{ml}$ per head per day whereas; the requirement is $250 \mathrm{ml}$ per head per day ${ }^{[2]}$. The average milk production of local cows is very low and it varies between 300 to 400 liters per lactation period of 180 to 240 days ${ }^{[3]}$. Generally crossbred cows yield from 600 to 800 liters per lactation of 210 to 240 days ${ }^{\text {[3] }}$. Therefore, milk production of our country is not satisfactory although we have a large number of milking cows and cattle populations. The number of milking cows in Bangladesh is 3.79 million. Of the total milking cows, only 1.09 per cent was reported to be crossbred ${ }^{[4]}$. The population of cattle in Bangladesh is about 24.5 million ${ }^{[5]}$. Despite such a high density of cattle population; we are suffering from an acute shortage of milk for long time. The shortage is attributing due to poor quality of cattle species leading to their low productivity.

Milk production depends on various factors such as breed of cows, age of cows, stage of lactation and number of lactation, genetic makeup as well as the nutritional status of the animals, genotype environment interaction and so on. Lactation has a significant effect on milk yield and quality. Milk yield increases gradually with advances of lactation number. The stage of lactation has also significant effect on milk yield. Milk yield decreases with advances of stages of lactation. The fat, SNF and TS content increases gradually with advances of stages of lactation. Therefore, the lactation and stage of lactation has remarkable effects on milk yield and quality. Many researches had been done all around the world on it ${ }^{[6-12]}$. But very few works had been done in our country ${ }^{[13]}$. Therefore, the present study was undertaken with the aim of investigating the effect of lactation order and stage of lactation on milk yield and fat content of raw milk from indigenous and crossbred dairy cows reared at village condition.

\section{MATERIALS AND METHODS}

\section{Sources and Description of Animals}

For this experiment a total of 18 milking cows belonging to different lactation number and different stages of lactation were selected. Nine of them were indigenous and the rest nine were crossbred. Both types of animals were reared under village condition. For this purpose three village areas Boyra, Sutiakhali and Kewatkhali surroundings to Bangladesh Agricultural University were selected. The animals of three lactation periods were used for this study. The information regarding milk yield were collected from the farmers with a related questionnaire.

Collection of samples

During experimental period a total of 54 samples of 
raw milk were collected from different stages of lactation and order of lactation of the selected milking cows.

\section{Statistical analysis}

The experiment was conducted by using Completely Randomized Design (CRD) to compute analysis of variance and to calculate the mean of each variance. Differences between means were evaluated for significant level following a modified Duncan's Multiple Range Test (DMRT). "MSTAT" was used for this purpose. F-value was calculated to find out significant difference between treatment means. LSD (Least significant difference) was also used for the comparison between the treatment means.

Table 1: Analysis of Variance Table for Milk Yield (Indigenous)

\begin{tabular}{ccccccc}
\hline $\begin{array}{c}\text { Source of } \\
\text { variation }\end{array}$ & $\begin{array}{c}\text { Degrees of } \\
\text { freedom }\end{array}$ & $\begin{array}{c}\text { Sum of } \\
\text { squares }\end{array}$ & $\begin{array}{c}\text { Mean } \\
\text { squares }\end{array}$ & F-value & Probability & evel of significance \\
\hline Factor A & 2 & 6.652 & 3.326 & 5.4267 & 0.0143 & \\
Factor B & 2 & 7.035 & 3.518 & 5.7394 & 0.0118 & \\
& & & & & & \\
AB & 4 & 1.337 & 0.334 & 0.5452 & & \\
Error & 18 & 11.032 & 0.613 & & \\
Total & 26 & 26.055 & & & \\
& & & & &
\end{tabular}

Table 2: Analysis of Variance Table for Milk Yield (Crossbred)

\begin{tabular}{|c|c|c|c|c|c|c|}
\hline $\begin{array}{l}\text { Sulce of } \\
\text { vanation }\end{array}$ & $\begin{array}{l}\text { Degresesof } \\
\text { frictodon }\end{array}$ & $\begin{array}{l}\text { Sumof of } \\
\text { squarrs }\end{array}$ & rean square & F-valluc & Problability & $\begin{array}{c}\text { Levelol } \\
\text { significinan }\end{array}$ \\
\hline Factor & 2 & 2.842 & 1.421 & 28.2652 & 0.00000 & \\
\hline Factor B & 2 & 2.677 & 1.314 & 26.1271 & 0.00000 & \\
\hline $\mathrm{AB}$ & 4 & 0.367 & 0.092 & 1.8260 & 0.1678 & \\
\hline Error & 18 & 0.0015 & 0.050 & & & \\
\hline Toxal & 26 & 6.742 & & & & \\
\hline
\end{tabular}

\section{RESULTS AND DISCUSSION}

Effect of number of lactation on average daily milk yield

The average daily milk yield of indigenous and crossbred cows at different number of lactation and stages of lactation was shown in Table 3 and Table 4. The average daily milk yields for different number of lactation of indigenous and crossbred Cows are presented in Table 5. It was found that the average daily milk yield of indigenous and crossbred cows at 1 st, 2nd and 3rd lactation were 1.31, 1.63, 2.07 and $8.91,9.57, \quad 10.17$ liter/day/cow, respectively. Statistical analysis showed that there was significant difference $(p<0.01)$ within the daily milk yield of different lactations both for indigenous and crossbred cows. Milk yield increased gradually from 1 st to $3 \mathrm{rd}$ lactation. The highest milk yield was recorded in 3rd lactation (2.500 liter /day for indigenous and 10.83 liter per day for crossbred) and lowest was in $1 \mathrm{st}$ lactation (1.083 liter/day for indigenous and 8.250 liter/day for crossbred). The overall milk production in different lactation for indigenous cows was 1.672 liter/day and for crossbred cows was 9.550 liter/day.
The lactation had strong significant difference $(p<0.01)$ on milk yield also disclosed ${ }^{[14,15]}$. An early work observed that lactation milk yield increased with lactation number ${ }^{[12]}$. In the early lactation, the animals are not in the productive stage and they remain in growing stage and at the same time their mammary gland and mammary vein are not well developed at that stage. Generally maximum milk yield is expected when the cows have grown fully at about 3rd or 4th lactation ${ }^{[15]}$. So the results of this study regarding lactation number support the results of above workers. A study represented the milk production performance of local cows with an average of $2.42 \pm 0.40$ liter/day ${ }^{[16]}$. Another study proposed the daily milk yield of 340 local cows to be of $1.63 \pm 0.72$ liter/day ${ }^{[17]}$. The milk yield performance of four genetic groups of Holstein Friesian $x$ half-bred heifers $\left(F_{1}, F_{2}, F_{3}\right.$ and $\left.F_{4}\right)$ along with Shahiwal in Bangladesh with a mean of 8.16 liters per day ${ }^{[18]}$. Average daily milk yield of $F_{1}, F_{2}$, $\mathrm{F}_{3}, \mathrm{~F}_{4}$ and Shahiwal were 10.02, 8.23, 8.59, 9.58 and 7.52 liter respectively found in local and crossbred cows under both farm and rural conditions in Bangladesh Agricultural University Dairy Farm and its adjacent villages studied ${ }^{[19]}$. In rural condition milk yield of local, Local $\times$ Sahiwal and Local $\times$ Sindhi were $2.6 \pm 0.23,7.9 \pm 0.52$ and $8.7 \pm 0.45$ liter/day respectively. In farm condition average daily milk yield of local, Local $\times$ Sahiwal, Local $\times$ Sindhi, Local $\times$ Jersey and Local $\times$ Friesian were $3.3 \pm 0.50$, $8.8 \pm 0.61,10.01 \pm 0.4$, and $10.2 \pm 0.48$ and $12.7 \pm 0.53$ liter/day, respectively. The result of present findings agrees with the results of above authors.

Table 3. Daily milk yield and quality parameters of Indigenous cows on different stage of lactation and number of lactation

\begin{tabular}{|c|c|c|c|c|c|c|c|c|}
\hline \multirow{2}{*}{$\begin{array}{l}\text { Param } \\
\text { eters }\end{array}$} & \multirow{2}{*}{$\begin{array}{l}\text { Stage of } \\
\text { Lactation }\end{array}$} & \multicolumn{4}{|c|}{ No. of Lactation } & \multicolumn{3}{|c|}{ SED(LSD) and Significance } \\
\hline & & 1 & 2 & 3 & Mean & $\begin{array}{l}\text { Stage of } \\
\text { Lactation }\end{array}$ & $\begin{array}{l}\text { No. of } \\
\text { Lacation }\end{array}$ & $\begin{array}{l}\text { Stage X } \\
\text { No. of } \\
\text { Lactation }\end{array}$ \\
\hline \multirow{4}{*}{$\begin{array}{l}\text { Milk } \\
\text { Yield( } \\
\text { 1/d) }\end{array}$} & 1 & $\begin{array}{c}1.31 \\
7\end{array}$ & 1.483 & 2.050 & 1.617 & \multirow[t]{4}{*}{0.2215} & \multirow[t]{4}{*}{0.2215} & \multirow[t]{4}{*}{$\begin{array}{c}0.1291 \\
\text { NS }\end{array}$} \\
\hline & 2 & $\begin{array}{c}1.53 \\
3\end{array}$ & 2.250 & 2.500 & 2.094 & & & \\
\hline & 3 & $\begin{array}{c}1.08 \\
3\end{array}$ & 1.167 & 1.667 & 1.306 & & & \\
\hline & Mean & $\begin{array}{c}1.31 \\
1\end{array}$ & 1.633 & 2.072 & 1.672 & & & \\
\hline
\end{tabular}

\section{Effect of stage of lactation on average daily milk yield}

For more clarification, milk samples were statistically analyzed on the basis of early, middle and later stages of lactation. As mentioned earlier first three months (1st to $3 \mathrm{rd}$ ) were considered at early stage, middle three months (4th to 6th) as middle stage and rest months (7th to rest) as later stage of lactation. The average daily milk yields for different stages of lactation of indigenous and crossbred cows are presented in Table 6. The mean milk yield of indigenous and crossbred cows at early, middle \& later stages of lactations were 1.62, 2.09, 1.31 and 9.39, 10.22, 9.04 liter/cow/day, respectively. The results revealed that stages of 
lactation had significant effect $(\mathrm{p}<0.01)$ on milk yield per day.

Table 4. Daily milk yield and quality parameters of Crossbred cows on different stage of lactation and number of lactation

\begin{tabular}{|c|c|c|c|c|c|c|c|c|}
\hline \multirow{2}{*}{ Parameters } & \multirow{2}{*}{$\begin{array}{l}\text { Ltage of } \\
\text { Lactation }\end{array}$} & \multicolumn{4}{|c|}{ No. of Lactation } & \multicolumn{3}{|c|}{ SED(LSD) and Significance } \\
\hline & & 1 & 2 & 3 & $\begin{array}{c}\text { Mea } \\
\mathrm{n}\end{array}$ & $\begin{array}{l}\text { Stage of } \\
\text { Lactation }\end{array}$ & $\begin{array}{l}\text { No. of } \\
\text { Lactation }\end{array}$ & $\begin{array}{l}\text { Stage x } \\
\text { No. of } \\
\text { Lactation }\end{array}$ \\
\hline \multirow{4}{*}{$\begin{array}{l}\text { Milk } \\
\text { Yield(I/d) }\end{array}$} & 1 & $\begin{array}{c}8.58 \\
3\end{array}$ & $\begin{array}{c}9.75 \\
0\end{array}$ & $\stackrel{9.83}{3}$ & $\begin{array}{c}9.38 \\
9\end{array}$ & \multirow{4}{*}{$\begin{array}{c}0.7754 \\
* * *\end{array}$} & \multirow{4}{*}{$\underset{* 774}{0.7754}$} & \multirow{4}{*}{$\begin{array}{c}0.4520 \\
\text { NS }\end{array}$} \\
\hline & 2 & 9.91 & 9.91 & 10.8 & 10.2 & & & \\
\hline & 3 & 8.25 & 9.03 & $\begin{array}{l}3.83 \\
9.83\end{array}$ & $\begin{array}{c}2.03 \\
9.03\end{array}$ & & & \\
\hline & Mean & $\begin{array}{c}0 \\
8.91 \\
7\end{array}$ & $\begin{array}{c}3 \\
9.57\end{array}$ & $\begin{array}{c}3 \\
10.1 \\
7\end{array}$ & $\begin{array}{c}9 \\
9.55 \\
0\end{array}$ & & & \\
\hline
\end{tabular}

Table 5. Effect of number of lactation on milk yield and quality parameters of Indigenous and Crossbred cows

\begin{tabular}{|c|c|c|c|c|c|c|c|}
\hline \multirow{2}{*}{ Parameters } & \multirow{2}{*}{$\begin{array}{c}\text { Genotyp } \\
\mathrm{e}\end{array}$} & \multicolumn{4}{|c|}{ No. of Lactation } & \multirow{2}{*}{$\begin{array}{l}\text { SED } \\
\text { (LSD) }\end{array}$} & \multirow{2}{*}{$\begin{array}{l}\text { Level of } \\
\text { Significa } \\
\text { nce }\end{array}$} \\
\hline & & 1 & 2 & 3 & $\begin{array}{c}\text { Overal } \\
1\end{array}$ & & \\
\hline \multirow{2}{*}{$\begin{array}{c}\text { Milk Yield } \\
\text { (I/d) }\end{array}$} & $\begin{array}{c}\text { Indigeno } \\
\text { us }\end{array}$ & 1.311 & 1.633 & 2.072 & 1.672 & 0.2215 & $* *$ \\
\hline & $\begin{array}{c}\text { Crossbre } \\
\mathrm{d}\end{array}$ & 8.917 & 9.567 & 10.167 & 9.550 & 0.7754 & ** \\
\hline
\end{tabular}

It was observed that milk yield decreased after 2nd stage of lactation and decreased linearly up to the end of lactation. The highest milk yield was recorded in 2nd stage of lactation (2.500 liter /day for indigenous and 10.83 liter per day for crossbred) and lowest was in 3rd stage of lactation (1.083 liter/day for indigenous and 8.250 liter/day for crossbred). Now a day, it is widely accepted that milk yield of the cow's decreases gradually as the lactation stages increases ${ }^{[1,7,13]}$.

Another study reported that from date of calving milk production started to increase gradually and highest milk yield was found at 2nd stage of lactation, there after milk production decreased gradually up to the end of the period ${ }^{[1]}$. Milk yield was higher in the first lactation stage morning milking as compare to other stages ${ }^{[10]}$. In a recent study it was observed that the milk yield of Lithuanian and German Black-and-White cows significantly increased during the sixth month of lactation ${ }^{[11]}$. The result of present study agrees with the results of above authors.

Table 6. Effect of stage of lactation on milk yield and quality parameters of Indigenous and Crossbred cows

\begin{tabular}{|c|c|c|c|c|c|c|c|}
\hline \multirow{2}{*}{ Parameters } & \multirow{2}{*}{ Genotype } & \multicolumn{4}{|c|}{ Stage of Lactation } & \multirow{2}{*}{$\begin{array}{l}\text { SED } \\
\text { (LSD) }\end{array}$} & \multirow{2}{*}{$\begin{array}{l}\text { Level of } \\
\text { Significance }\end{array}$} \\
\hline & & 1 & 2 & 3 & Overall & & \\
\hline \multirow{2}{*}{$\begin{array}{c}\text { Milk Yield } \\
\text { (1/d) }\end{array}$} & Indigenous & 1.617 & 2.094 & 1.306 & 1.672 & 0.2215 & *** \\
\hline & Crossbred & 9.389 & 10.222 & 9.039 & 9.550 & 0.7754 & ** \\
\hline
\end{tabular}

From the above discussions, it may be concluded that crossbred cows are superior to indigenous in concern of milk yield. Other parameters are more or less same for both indigenous and crossbred cows. So, we should rear more crossbred cows for more profitability and production and we shall be able to meet up the increasing demand of milk and alleviate poverty of our country.

\section{REFERENCES}

1. Eckles CH, Conbs WB and Maey H (1951). Milk and milk products, fourth edition, McGrow Hill Book Company, Newyork, Toronto, London. pp:49-69.

2. DLS (2002). Directorate of Livestock Services. An overview, DLS, Dhaka, Bangladesh.

3. Hossain MA and Routledge SF (1982). Performance of crossbred and local cattle under village condition in Pabna district of Bangladesh. A paper presented at the seminar on Proceeding of "maximum livestock production of a minimum land". Bangladesh Agricultural Research Institute, Joydebpur, 15 to 18 February, pp. 161-167.

4. BBS (2002). Statistical Yearbook of Bangladesh. Bangladesh Bureau of Statistics. Ministry of Planning. p: 623.

5. FAO (2004). Selected indicators of food and agricultural development in Asia-Pacific region, 1993-2003. Food and Agricultural Organization of United Nations, Bangkok, Thailand. pp: 119-121.

6. Turner CW (1936). Factors affecting the composition of milk. Missouri Agricultural Expt. Sta. Bull. p:365.

7. Aggarwala AC and Sharma RM (1961). A laboratory manual of milk inspection. Fourth edition. Asian publishing house, Bombay.

8. Jain DK, Sharma KNS, Bhatnanagar DS and Sharma RC (1985). Fat and SNF concentration in cow milk as affected by parity and stage of lactation. National Dairy Research Institute, Karnal-132001, Received $29^{\text {th }}$ August 1985.

9. Venkatachalapathy RT and Sosamma I (1998).Fat, total solids and solids-not-fat percentage of milk in Vechur cattle. Indian Journal of Animal Science. 68(6): 570-573.

10. Sekerden O (2002). Relationships between lactation stage with milk yield and constituents, and heritabilities of milk constituents. Hayvansal Uretim Journal of Animal Production. 43(2): 6167.

11. Pauliukas K, Sidiskis AR, Urbonavicius A and Serenas K (2005). Effect of lactation and other factors on the changes of milk composition and its qualitative parameters in Black-and-White cows. Veterinarija-ir-Zootechnika. 30: 67-71.

12. Kocak O and Ekiz B (2006). Studies on factors affecting the milk yield and lactation curve of 
Holstein cows in intensive conditions. Veteriner Fakultesi Dergisi Istanbul. 32(2): 61-69.

13.Hossain AM (1968). A study of average percentage of fat, total solids, solids-not-fat content of local cows milk and the variation of milk fat percentage with the stage of lactation. M. Sc (AH) Dairy Science, East Pakistan (Now Bangladesh) Agricultural University, Mymensingh.

14. Lal D and Narayanan KM (1990). A correlation study between milk composition and yield with lactation number and stage of lactation. Indian Journal of Animal Sciences. Vol. 60 No. 6 pp. 735-737

15. Choudhury MZ and Barhat NK (1979). Effect of cross breeding and certain environmental factors on level of milk production in cattle. Indian Journal of Animal Science, 49(8): 604-607.
16. Jabbar MA and Ali SZ (1988). The limitation of crossbreeding for improvement of cattle in Bangladesh. Oxford Agrarian Studies. 19: 325327.

17. Bhuiyan AKFH and Faruque MO (1993). Yield and variability of milk production in the local cattle of Bangladesh. Proceeding of the BAURES workshop, vol.8: 440-443.

18. Chaudhury MZ, Tahir MJ and Rafique M (1994). Production and milk production efficiency in different filial groups of Holstein Friesian $\mathrm{x}$ Sahiwal half- breds. Asian Australasian Journal of Animal Science, 7(3): 383-387.

19. Husain SS and Mostafa KG (1985). Reproductive potentialities of local and crossbred animals under farm and village condition. Livestock advisor, $\mathrm{X}$ : 15-19 